\title{
Burdens of Proof in Civil Litigation: An Economic Perspective
}

\section{Citation}

Bruce L. Hay \& Kathryn E. Spier, Burdens of Proof in Civil Litigation: An Economic Perspective, 26 J. Legal Stud. 413 (1997).

\section{Published Version}

http://dx.doi.org/10.1086/468002

\section{Permanent link}

http://nrs.harvard.edu/urn-3:HUL.InstRepos:12206463

\section{Terms of Use}

This article was downloaded from Harvard University's DASH repository, and is made available under the terms and conditions applicable to Other Posted Material, as set forth at http:// nrs.harvard.edu/urn-3:HUL.InstRepos:dash.current.terms-of-use\#LAA

\section{Share Your Story}

The Harvard community has made this article openly available.

Please share how this access benefits you. Submit a story.

\section{Accessibility}




\title{
BURDENS OF PROOF IN CIVIL LITIGATION: AN ECONOMIC PERSPECTIVE
}

\author{
BRUCE L. HAY and KATHRYN E. SPIER*
}

\begin{abstract}
Burden of proof rules, which require a specified party to produce evidence on a contested issue, are central to the adversary system. In this article, we model burden of proof rules as a device for minimizing the costs of litigation. The central point to emerge from the model is that, properly assigned, a burden of proof rule economizes on the transmission of information to the court. We use the model to explain characteristic practices of courts in assigning the burden of proof.
\end{abstract}

\section{INTRODUCTION}

A DVERSARY systems of justice typically give the parties (not the judge) the task of adducing evidence on contested issues in litigation. ${ }^{1}$ Such a policy immediately raises the problem of dividing that task between the parties. Who, as between plaintiff and defendant, should be given the job of producing evidence on a contested issue? Burden of proof rules are the device courts employ to address this problem. By giving a specified party the burden of proof on a given issue, the court tells that party that he must either come up with evidence supporting his position or suffer an adverse judgment on that issue.

In this article we develop an economic analysis of the assignment of burdens of proof in civil litigation. Our principal claim is that courts can use the burden of proof to limit the costs of resolving a dispute. More precisely, we argue that the burden of proof, by giving one party the task of producing evidence, relieves his opponent to some extent of that task-thereby saving expenditures that might otherwise be incurred by the opponent. Optimally used, the burden of proof may minimize the expenditures devoted to gather-

* Bruce L. Hay is Assistant Professor at Harvard Law School. Kathryn E. Spier is Associate Professor, Kellogg School of Management, Northwestern University. Earlier versions of this article were presented at workshops at Harvard, Chicago, Michigan, and Stanford. We thank Louis Kaplow, Steven Shavell, Bernard Wolfman, and the workshop participants for their comments.

1 This is, as Wigmore observed, a characteristic feature of Anglo-American legal systems. See John H. Wigmore, 9 Wigmore on Evidence 276 (Chadbourn rev 1970).

[ Journal of Legal Studies, vol. XXVI (June 1997)]

(C) 1997 by The University of Chicago. All rights reserved. 0047-2530/97/2602-0005 $\$ 01.50$ 
ing, presenting and processing information in litigation. This rationale, we suggest, is consistent with the observed practices of court in making the burden of proof assignment.

To make these points, we use a simple model of litigation in which the parties decide strategically whether to present evidence, given the burden of proof rule selected by the court. The court's problem in the model is to choose the burden of proof that minimizes the costs of litigation. Section II of this article introduces the model and specifies the court's problem. Section III examines how, in the model, the parties will behave under alternative burden of proof assignments. Building on these results, Section IV identifies the optimal burden of proof assignment and the factors on which it turns. Section V considers the extent to which the model holds up as a positive theory of how courts assign the burden of proof in practice. Section VI concludes.

\section{The Problem}

\section{A. Two Types of Decision Rule}

Consider a lawsuit in which a contested issue is whether some event $X$ occurred; the plaintiff says $X$ occurred, the defendant says it did not ( $X$ might be, for example, an act of negligence by the defendant). The governing substantive law, we may assume, holds that the defendant's liability to the plaintiff depends on whether $X$ in fact occurred.

Taken alone, that substantive rule is not enough to decide cases such as this, in which the parties make conflicting assertions. The court also needs a rule instructing it on what to do when it is uncertain whether $X$ occurred. Two possible components of such a rule are worth distinguishing.

Level of Confidence. A level of confidence rule (or "standard of proof"') is a principle specifying how certain the court must be of a fact to accept it. In abstract terms, such a rule would specify a threshold of $T$ percent: if the court believes the probability that $X$ occurred exceeds $T$, it finds for the plaintiff on the issue and otherwise finds for the defendant. Standards of proof such as "beyond a reasonable doubt," "clear and convincing evidence," and "preponderance of the evidence" represent different possible choices of a value for $T$. $^{2}$

Burden of Proof. In an adversary system, the court generally cannot

${ }^{2}$ As we have formulated it, the rule specifying $T$ incorporates the so-called burden of persuasion-a principle for decision in cases where the trier of fact is in equipoise-in civil cases. If, for example, $T>50$ percent, then the plaintiff has the burden of persuasion, in the sense that the defendant wins if the court thinks $X$ is equally likely to have happened or not to have happened. 
conduct its own search for information concerning $X$ 's occurrence; it must wait to see what evidence the parties present. The function of a burden of proof rule is to apportion the task of presenting evidence. In effect, a burden of proof rule requires one party to produce evidence sufficient to convince the court (to the required level of confidence) of his position. Thus, if the plaintiff has the burden of proof, he loses if no evidence is introduced that $X$ occurred; if the defendant has the burden of proof, he loses unless evidence is introduced that $X$ did not occur.

Now, the distinction between a rule indicating the required level of confidence and a rule indicating a burden of proof is of course blurry. ${ }^{3}$ (As we use the term, "burden of proof" corresponds to the so-called burden of production commonly encountered in textbooks. $)^{4}$ For our purposes, the important line of demarcation is that a burden of proof rule-as we use the term here-specifies who must present evidence to the court. ${ }^{5}$ It is important to see that this question is not the same as asking how certain the court must be of $X$ before concluding it occurred.

This may not be obvious. It might be thought that a rule indicating the required level of confidence necessarily implies a corresponding burden of proof. The line of reasoning would go as follows: if the threshold $T$ for imposing liability is greater than 50 percent, then this must mean the court must rule in the defendant's favor if no evidence is introduced (in other words, the plaintiff has the burden of proof). That is because, if no evidence is introduced, the court must conclude the parties' positions are equally likely to be true, in which case (since $T>.5$ ) the defendant must win. ${ }^{6}$

To see the error in this reasoning, consider the follow example. Suppose that both parties have access to evidence giving a perfectly accurate signal of whether $X$ occurred $;{ }^{7}$ suppose both parties know what the evidence contains; and suppose that both parties believe (for whatever reason) that if no evidence is introduced, the court will rule for the plaintiff. Suppose, finally,

${ }^{3}$ Deciding how much evidence is necessary to discharge a party's burden of proof is similar, if not identical, to deciding what level of confidence the court should have before imposing sanctions.

${ }^{4}$ In contrast, the burden of persuasion is included in the rule specifying the required level of confidence. See note 2 above. For a discussion of the burdens of persuasion and production, see Fleming James, Jr., Geoffrey C. Hazard, Jr., and John Leubsdorf, Civil Procedure 337-43 (4th ed 1992).

${ }^{5}$ An inquisitorial system in its pure theoretical form-which gives the court the task of gathering evidence-would not have a burden of proof as we have described it. An inquisitorial system would, however, need to specify the required level of confidence necessary to conclude that $X$ occurred.

${ }^{6}$ Similarly, if $T$ is less than 50 percent, then this must mean the court must rule in the plaintiff's favor if no evidence is introduced (so the defendant bears the burden of proof).

${ }^{7}$ Say, a videotape whose authenticity is undisputed. 
that the court knows all this (but does not know what the contents of the evidence is). Then, if the court sees no evidence introduced, it should conclude that $X$ occurred: for if the evidence showed otherwise, the defendant would have introduced it.

The important thing to see in this example is that it makes no difference what level of confidence is required: $T$ can be 1 percent or 99 percent; the analysis is the same no matter what its value. So long as the court knows the defendant could have introduced perfectly reliable evidence of his care but chose not to, it can conclude the defendant was negligent. In short, the value of $T$ does not imply who should lose in the event no evidence is introduced.

This example is obviously stylized, but its point holds more broadly: the choice of a burden of proof is logically independent of the choice of a rule specifying the required level of confidence. The simple reason for this is that the parties decide strategically whether to introduce evidence, based on what they expect the court to do if no evidence is introduced. Given the parties' beliefs in the above example, it is perfectly coherent for the court to put the burden of proof on the defendant even though $T$ may be very large; similarly, it would (if the parties had other beliefs) be coherent for the court to put the burden of proof on the plaintiff even if $T$ were very small.

\section{B. The Court's Task}

Our interest will be in the problem of choosing a burden of proof on some issue in litigation, given some rule specifying the required level of confidence. To examine the court's problem, we use a simple model of litigation in which each party decides whether to gather, and present to the court, evidence on the issue of negligence; the court then rules in one or the other's favor on that issue. (We put aside the possibility of settling out of court.)

For clarity of exposition, we make the following set of assumptions about the litigation: (1) Both parties have access to a body of evidence that indicates (to the required level of certainty) whether the defendant acted negligently, and both parties know what the evidence contains. (2) This body of evidence is unitary in nature, so that the court sees either all of it or none of it. (This latter assumption might be justified on the hypothesis that if one party tries to mislead the court by a selective presentation of the evidence, the other party furnishes the rest of the evidence. $)^{8}$ (3) A party's cost of

\footnotetext{
${ }^{8}$ We make this assumption because (1) it enables us to put aside level-of-confidence issues (how much evidence should be required?) and (2) it enables us to put aside strategic problems associated with partial presentation of the evidence.
} 
presenting the evidence is sufficiently low that he will present evidence on the issue of negligence, if presenting it is necessary to secure a favorable ruling on the issue.

\section{Parties' Behavior under Alternative Burden Assignments}

As a predicate to examining the court's problem, we begin by identifying how the parties will act in litigation under one or the other burden of proof assignment. Suppose the plaintiff has the burden of proof on whether $X$ occurred. Then the parties, assuming they are informed of the burden assignment, will behave as follows in equilibrium:

The plaintiff presents the evidence if and only if it indicates $X$ occurred.

The defendant presents no evidence on the question.

To see that this behavior holds (uniquely) in equilibrium, observe first that the defendant has a dominant strategy of introducing no evidence. If the evidence shows that $X$ occurred, there is no point in presenting it; doing so would either cause him to lose (if the plaintiff does not present the evidence) or have no effect on the outcome (if the plaintiff does present it) and force him to incur presentation costs. Better, in either event, to save the costs of presenting the evidence. If, instead, the evidence shows $X$ did not occur, there is also no point in introducing it: he will win on the issue whether or not the evidence is introduced (since the plaintiff has the burden of proof), so again he may as well save the costs of presenting it. No matter what strategy the plaintiff follows, then, the defendant will present no evidence.

Now consider what the plaintiff will do, given this strategy of the defendant's. If the evidence shows $X$ occurred, the plaintiff will present the evidence: she cannot rely on the defendant to present the evidence, and if no one presents it she will lose on the issue. If, instead, the evidence shows $X$ did not occur, there is no point in presenting the evidence-doing so would bring defeat on herself and saddle her with presentation costs to boot. Thus, the above strategy profile constitutes the unique equilibrium when the plaintiff has the burden of proof.

A similar analysis shows that, if the defendant has the burden of proof, the parties will pursue the following strategies in equilibrium:

The plaintiff presents no evidence on whether $X$ occurred.

The defendant presents the evidence if and only if it indicates $X$ did not occur. 
The intuition here is the same as in the previous case, except that the parties' roles are reversed. The plaintiff has no reason to incur the cost of presenting the evidence, whether or not it shows $X$ occurred-since in either event presenting it will have no effect on the outcome of the case. The defendant will accordingly want to present the evidence if it supports his position, but not otherwise.

In summary, then, under either burden of proof assignment, the party with the burden will present the evidence if and only if the evidence supports his position, while the other party will refrain from presenting evidence regardless of whether the evidence supports his position. ${ }^{9}$

\section{Optimal Burden Assignments}

\section{A. The Basic Model}

We turn now to the optimal assignment of the burden of proof. Our objective is to examine how the court may use the burden of proof to economize on the transmission of information in litigation. Let us suppose that the court wants to assign the burden of proof to minimize the expected costs of presenting evidence on whether $X$ occurred. Then the court should give the plaintiff the burden if the following expression holds:

\begin{tabular}{|ll}
\hline $\begin{array}{l}\text { probability } \\
\text { that } X \\
\text { occurred }\end{array}$ & $\begin{array}{l}\text { plaintiff's costs } \\
\text { of showing } X \\
\text { occurred }\end{array}$
\end{tabular}$<\begin{array}{ll}\begin{array}{l}\text { probability } \\
\text { that } X \text { did } \\
\text { not occur }\end{array} & \begin{array}{l}\text { defendant's costs } \\
\text { of showing } X \text { did } \\
\text { not occur }\end{array}\end{array}$.

This follows from our analysis of the parties' equilibrium behavior. As we have seen, the plaintiff will present the evidence (given the burden of proof) if and only if it establishes that $X$ occurred. Thus, the left-hand box indicates the expected costs of giving the burden to the plaintiff. Similarly, the

\footnotetext{
${ }^{9}$ In this model the court has committed itself in advance to a given burden of proof assignment. One might ask what would happen if, alternatively, the court were a player in this game and decided cases according to its posterior beliefs (given the parties' actions in the litigation) about whether $X$ occurred. Interestingly, the strategies just described are equilibrium outcomes in this game as well. For example, if the parties believe that the court will rule for the plaintiff in the event no evidence is introduced, then the defendant will present evidence if and only if the evidence favors him. Accordingly, if no evidence were introduced, the court would infer that the evidence favored the plaintiff and would rationally rule for the plaintiff. In this way, the strategies described in the text may arise endogenously in a threeplayer version of the game. One way of viewing burden of proof rules, therefore, is as a mechanism for selecting between different Nash equilibria. We explore this point in more detail in a previous version of this paper. See Bruce L. Hay and Kathryn E. Spier, "The Economics of the Burden of Proof" (unpublished manuscript, April 1994).
} 
right-hand box indicates the expected costs of assigning the burden to the defendant.

As (1) shows, two basic factors determine the optimal assignment in this setting. ${ }^{10}$ Let us consider them in turn.

\section{Parties' Costs}

The first factor is the parties' relative costs of gathering and presenting evidence on the contested issue. One party may have easier access to evidence than his opponent, meaning he can assemble the appropriate evidence at lower cost than his opponent. Other things being equal, the lower one party's relative costs, the stronger the argument for giving him the burden of proof.

This question is complicated by the existence of discovery rules, which enable each party to demand the evidence in the other's possession. But discovery does not render irrelevant the question of relative presentation costs because the costs of discovery should be counted as presentation costs. Suppose, for example, that the defendant has exclusive possession of relevant evidence. Giving the plaintiff the burden of proof may lead her to demand, and sift through, piles of information that may or may not contain useful evidence-generating costs that might be avoided if the defendant were given the burden of proof. ${ }^{11}$ Determining the parties' relative costs thus requires the court to decide who initially possesses what evidence and how costly and effective the discovery process is.

\section{Probabilities}

The court begins with some information $Y$ about the case; we will call $Y$ the "signal" the court has received about whether $X$ occurred. Given $Y$, the probability that $X$ occurred is as follows:

$$
\frac{\operatorname{prob}(X \mid Y) \times \operatorname{prob}(X)}{\operatorname{prob}(Y)} ;
$$

${ }^{10}$ These factors are widely recognized as the essential ones in assigning the burden of proof on an issue. See, for example, James, Hazard, and Leubsdorf, at 344-49 (cited in note $4)$.

${ }^{11}$ Here we have in mind a setting in which the defendant, but not the plaintiff, knows which files (or which witnesses' memories) contain useful evidence. Since the plaintiff will not believe a defendant's claim that a certain file is a dry well, she may rationally demand it and search through it-though it may indeed turn out to be a dry well. 
similarly, the probability that $X$ did not occur is

$$
\frac{\operatorname{prob}(Y \mid \sim X) \times \operatorname{prob}(\sim X)}{\operatorname{prob}(Y)} .
$$

In these expressions, which are derived from Bayes' Rule, $\operatorname{prob}(X)$ represents the unconditional likelihood that $X$ will occur; ${ }^{12} \operatorname{prob}(\sim X)$ represents the unconditional likelihood that $X$ will not occur; $\operatorname{prob}(Y \mid X)$ is the likelihood the court would observe $Y$ if $X$ were to $\operatorname{occur} ; \operatorname{prob}(Y \mid \sim X)$ is the likelihood the court would observe $Y$ if $X$ were not to occur; and $\operatorname{prob}(Y)$ is the unconditional likelihood of observing $Y$. For purposes of deciding whether (1) holds, what matters is the two terms in the numerators of these expressions.

Begin with the term $\operatorname{prob}(X)$ in expressions (2) and (3). This term in effect represents how frequently $X$ occurs. The less frequently $X$ occurs, the less likely that it occurred in this case. For example, suppose the case is a medical malpractice suit arising out of an unsuccessful surgical operation. Assume that

$X \equiv$ surgeon's failure to exercise due care.

If surgeon carelessness is a highly infrequent event, then-all else being equal - the court should believe that it probably did not occur in this case. (We will see below how all other things may not be equal.) Conversely, if surgeons are frequently careless, then-again, all else being equal-the court should conclude that the surgeon was probably careless in this case.

Now consider the terms $\operatorname{prob}(Y \mid X)$ and $\operatorname{prob}(Y \mid \sim X)$. Their relative magnitude tells us, in effect, how much information can be gleaned from knowing that $Y$ occurred. On the one hand, if $\operatorname{prob}(Y \mid X)$ is a lot greater than $\operatorname{prob}(Y \mid \sim X)$, then observing $Y$ is a good indication that $X$ occurred. For example, suppose that, in our malpractice example,

$Y \equiv$ a surgical implement is left inside the patient.

For purposes of this example let us assume that a careful surgeon would virtually never leave a surgical implement inside a patient, while a careless surgeon might well do so. Observing that an implement was left in the patient in this particular case is then a strong indication that the surgeon was negligent.

On the other hand, if $\operatorname{prob}(Y \mid X)$ is not much greater than $\operatorname{prob}(Y \mid \sim X)$,

${ }^{12}$ For example, if $X$ refers to negligent driving, $\operatorname{prob}(X)$ is the likelihood that motorists drive negligently. 
then not much information can be gleaned from $Y$ 's occurrence. In our example, suppose only that

$Y \equiv$ unsuccessful operation.

Let us assume that the operation in question often fails even when the doctor performs it carefully (though failure is more likely if the doctor is careless). Observing that the operation was unsuccessful in this case is not a strong indication that the doctor was negligent since the operation might well have failed even if the doctor had been careful.

\section{B. Refinements to the Basic Model}

\section{The Possibility of Settlement}

Suppose the parties can settle out of court without gathering or presenting any evidence to the court. This is what we would expect in cases where the parties are (as we have assumed) symmetrically informed about the evidence. Does the burden of proof assignment matter (in the sense of affecting the costs of litigation) in such instances? If so, do the prescriptions of the basic model apply to these cases?

The main effect of the burden assignment in such cases is to determine the size of the surplus from settling the case. Anytime there is a range of possible settlement amounts, there is the possibility of a costly bargaining process, in which each party attempts to capture as large a share of the surplus as possible; from a social standpoint, such bargaining investments represent a deadweight loss. In a world where cases settle, the burden assignment may (by establishing the size of the settlement surplus) influence the amount expended on bargaining. ${ }^{13}$

While we do not model this matter formally, the intuition can be expressed quite simply. Take a case in which $X$ has in fact occurred. As our analysis of the parties' equilibrium litigation strategies showed, evidence will be presented (in the event of trial) if the plaintiff, but not if the defendant, has the burden. Thus, putting the burden on the plaintiff in this case has the effect of creating a settlement surplus-namely, the plaintiff's presentation costs; to settle, the parties must agree on a division of that surplus, which may consume bargaining resources. This deadweight loss would be avoided, in this example, if the defendant had the burden of proof. (By anal-

${ }^{13}$ For elaboration of this point, see Bruce L. Hay, Allocating the Burden of Proof, 72 Ind L J (1997, in press). 
ogy, if $X$ has in fact not occurred, giving the defendant the burden creates a deadweight loss that could be avoided by giving the plaintiff the burden.)

What is the best assignment, given that the court does not know whether $X$ occurred? The court wants to assign the burden in a way that minimizes expected bargaining costs. We have the following result: if the resources consumed in settlement bargaining in a given case increase (in a linear fashion) as the settlement surplus increases, then the court's problem is the same as in the basic model; it achieves its objective by choosing the assignment that minimizes expected presentation costs (the costs that would be expended if the case failed to settle). If, however, bargaining costs do not vary in a linear fashion with the size of the surplus, the court's optimal assignment in a world of settlement will not necessarily be the same as in the basic model.

\section{Drawing Inferences from Parties' Litigation Decisions}

The court's information set at the time it assigns the burden, $Y$, includes the fact that the plaintiff has chosen to sue the defendant. But the plaintiff would not waste her time bringing a suit she expected to lose, and if $X$ did not occur, the verdict will be against her no matter how the burden is assigned. ${ }^{14}$ One might argue, therefore, that $Y$ (the fact that suit was brought) is a strong indication that $X$ occurred. Should not the court then conclude, from the fact suit was brought, that $\operatorname{prob}(X \mid Y)$ is large?

This reasoning overlooks that the plaintiff might sometimes bring a nonmeritorious claim in the hopes of extracting a settlement from the defendant. In particular, if the defendant bears the burden of proof, he will be willing to pay a positive amount to settle the case, in order to avoid the costs of proving that $X$ did not occur. The plaintiff, knowing this, may rationally choose to sue regardless of the merit of her claim. Accordingly, the plaintiff's decision to sue is not necessarily a strong indication that $X$ occurred. $^{15}$

\section{Assignment's Effect on Primary Behavior}

If $X$ is an action by one of the parties, then it might be asked whether its occurrence is affected by how the burden is assigned. Suppose, to return to

${ }^{14}$ This is clear from our analysis of the parties' equilibrium litigation strategies. Assume $X$ did not occur. If the plaintiff has the burden, she will present no evidence and lose the case. If the defendant has the burden, he will present the evidence and win the case.

${ }^{15}$ A similar argument shows that the defendant's decision to deny that $X$ occurred is not necessarily a good signal of whether $X$ occurred.

Steven Shavell has recently investigated an analogous problem in the context of appealsnamely, whether a court, in deciding whether an appeal is meritorious, should draw inferences from the fact that it was brought. See his article, The Appeals Process as a Means of Error Correction, 24 J Legal Stud 379, 412 (1995). 
our example, that $X=$ negligent behavior. Might not the defendant's decision whether to comply with the standard of care depend on who has the burden of proof?

Interestingly, if our simplifying assumptions about the litigation hold, ${ }^{16}$ we get the following result. If the standard of care is efficient, then the burden of proof assignment will not affect the defendant's decision to take care. (By "efficient'" we mean that, at the margin, the costs of precautions are less than the reduction in expected harm to the plaintiff.) We leave a demonstration of this point to the Appendix; the basic intuition is simple. From our analysis of the parties' strategies in equilibrium, we know that the defendant will (no matter who has the burden) be held liable if negligent, and not otherwise. But if the standard of care is efficient, the threat of liability will be enough to induce him to take care. In equilibrium, then, we would normally expect the defendant to (have an incentive to) take care regardless of how the burden is assigned.

Now, this result depends on the assumption that the standard of care is efficient (as well as on the other simplifying assumptions of the model). If these assumptions do not hold, there is no way of showing a priori that the burden of proof has no effect on the defendant's decision to take care. We make no claim about the extent to which, in reality, the assignment of the burden of proof affects actors' primary behavior. To the extent it does not have any such effect, however, two consequences follow. First, in searching for the optimal burden of proof, the court can focus on the burden's effect on litigation costs; it need not worry that the assignment will affect other social costs, such as the accident rate. Second, in evaluating (2) and (3), the court can treat $\operatorname{prob}(X)$ as being an independent variable, not influenced by the burden assignment.

\section{The Burden of Proof in Practice}

How well does the basic model comport with burden of proof assignments actually made by courts? We can restate the prescription of the basic model as follows. Plugging (2) and (3) into (1) and simplifying, we see that (1) is satisfied if and only if

$$
\begin{gathered}
\operatorname{prob}(Y \mid X) \times \operatorname{prob}(X) \times \text { plaintiff's costs } \\
<\operatorname{prob}(Y \mid \sim X) \times \operatorname{prob}(\sim X) \times \text { defendant's costs. }
\end{gathered}
$$

The basic model states that the court should give the plaintiff the burden of proof if (4) holds, but not otherwise.

16 That the parties are symmetrically informed and the cost of presenting evidence is low in relation to the stakes. 
We want to know how well this holds up as a description of what courts do in practice. In rough terms, the following seems a fair characterization of existing practices. (a) As a general rule, the plaintiff bears the burden of proof on most contested issues. There is, in a manner of speaking, a "presumption" that the plaintiff has the burden of proof on most factual issues in the litigation. (b) There are, however, a number of instances in which the defendant is given the burden of proof on a given issue. Though we do not examine this matter exhaustively, we think the model is consistent with both the general rule and some major exceptions.

\section{A. The General Rule}

A striking feature of judicial practice is that, in cases that go to court, the burden of proof is seldom put in question. On most contested issues in most cases, the plaintiff does not even bother disputing that she bears the burden of proof. This is presumably because courts only reluctantly entertain arguments for giving the defendant the burden of proof. To what extent is expression (4) consistent with a general rule that the plaintiff gets the burden of proof?

Let us suppose the court wanted to establish a presumption (or default rule) that the burden of proof rests on one party on all issues in all cases. That is, suppose it wanted to say the burden always rests on one party, unless the circumstances clearly warranted giving it to the other party. (The rationale for such a presumption, of course, would be to limit the resources expended on litigating the question of who should bear the burden of proof in a given case.) Who would get the burden under this default rule?

Expression (4) suggests that the following conditions, if satisfied, would justify giving the burden to the plaintiff:

i) in general, the plaintiff's costs of gathering and presenting evidence on a contested issue are not substantially greater than the defendant's; and

ii) actors generally comply with the law, regardless of how the burden of proof is assigned; thus, if $X$ refers to some sort of "wrongdoing" (commission of a tort, breach of contract, and so on), $\operatorname{prob}(X)$ is relatively low; and

iii) $\operatorname{prob}(Y \mid \sim X)$ is not too low, that is, the signal received by the court (before assigning the burden) has a possible "innocent" explanation, in the following sense: the signal might have been received even if the defendant had complied with the law.

We conjecture that these conditions are often met in practice-or more precisely, that courts might plausibly believe they are met in practice. Regarding $i$, it is reasonable to assume that, given the availability of discovery, parties' costs will often be roughly identical, though of course they will not 
always be so. Regarding ii, it seems safe to assume that much of the time, the threat of liability (along with other forces) induces actors to comply with applicable standards of tort law, contract law, and so forth.

If we grant those two assumptions, then condition iii is relatively easy to satisfy. A numerical illustration may help make the point. Let us suppose that the plaintiff's costs of gathering and presenting evidence are 50 percent higher than the defendant's, and let us suppose that actors comply with the applicable standard of care 90 percent of the time. ${ }^{17}$ Plugging this information into (4), we see that the plaintiff should have the burden of proof if

$$
\operatorname{prob}(Y \mid X) \times .1 \times 1.5<\operatorname{prob}(Y \mid \sim X) \times .9,
$$

that is,

$$
\operatorname{prob}(Y \mid X)<6 \times \operatorname{prob}(Y \mid \sim X) .
$$

Thus, the court should give the plaintiff the burden unless noncompliance with the law is six times more likely (than compliance is) to send the "signal" received by the court. The upshot is that, unless $Y$ is a fairly reliable signal of whether $X$ occurred, conditions $i$ and ii are enough to warrant giving the burden to the plaintiff.

\section{B. Exceptions}

Where exceptions to the general rule are made, we would expect to see them in situations where the plaintiff's costs are a lot greater than the defendant's, where $\operatorname{prob}(Y \mid X)$ is a lot greater than $\operatorname{prob}(Y \mid \sim X)$, or where the frequency of $X$ is very large. Let us consider some of the major exceptions.

\section{Res Ipsa Loquitur}

Courts invoke this principle to give the defendant the burden of proof on the issue of his own negligence, in cases involving accidents that generally result from negligence. ${ }^{18}$ (Our earlier malpractice example, involving a surgical implement left inside a patient, is a characteristic occasion for invoking the doctrine. $)^{19}$ Similarly, in product liability suits, the doctrine is used to give the defendant the burden of proving that the product causing injury was not defective, when the accident in question generally results from de-

${ }^{17}$ Thus, $\operatorname{prob}(X)=.1$.

${ }^{18}$ Numerous instances of the doctrine's application are collected in Fowler V. Harper, Fleming James, and Oscar Gray, 4 The Law of Torts 21-84 (2d ed 1986); and Wigmore, at 487-511 (cited in note 1).

${ }^{19}$ See, for example, Hestbeck v Hennepin County, 297 Minn 419, 212 NW2d 361 (1973). 
fective products. ${ }^{20}$ Consider, for example, in such cases, $\operatorname{prob}(Y \mid X)$ is much higher than $\operatorname{prob}(Y \mid \sim X)$. In deciding whether to apply the rule, some courts also ask whether the defendant had "exclusive" control over the instrumentality that the caused the injury; this might be justified on the grounds that exclusive control implies the defendant has greater access to evidence of what happened..$^{21}$ Res ipsa is, then, quite easy to square with expression (4).

\section{Presumptions}

Courts often presume the truth of a factual statement that is almost always true.${ }^{22}$ Consider, for example, the presumption that a letter or telegram reaches its designated addressee; that a person inexplicably absent from home for 7 years is deceased; that the presumption (in insurance coverage cases) that a sudden death is the product of accident rather than suicide; that the maker of a will is sane. ${ }^{23}$ Or consider the presumption that the price an investor pays for a security is influenced by accountants' opinion letters and the like. ${ }^{24}$ In these instances $\operatorname{prob}(X)$ is high, so the defendant is given the burden of producing supporting evidence that it did not occur. ${ }^{25}$

Other presumptions are justified by differentials in the parties' costs of gathering and producing evidence. Consider, for example, the presumption that damage to goods in a bailee's possession was caused by the bailee's negligence, or the presumption that the driver of another person's auto is acting as the owner's agent. ${ }^{26}$ Evidence about what happened to the damaged goods, or about the relation between the driver and the owner, is more

${ }^{20}$ Consider the famous line of cases involving exploding soft drink bottles (for example, Escola v Coca-Cola Bottling Co of Fresno, 24 Cal2d 453, 150 P2d 436 (1944)). Other examples are collected in the works cited in note 18 above.

${ }^{21}$ See Harper, James, and Gray, at 45-47 (cited in note 18), for examples. Exclusive control also increases the value of $\operatorname{prob}(X \mid Y)$ since it makes less likely the hypothesis that someone else's negligence injured the plaintiff.

22 "A presumption upon a matter of fact, when it is not merely a disguise for some other principle, means that common experience shows the fact to be so generally true that courts may notice the truth." Greer v United States, 245 US 559, 561 (1918) (Holmes, J).

${ }^{23}$ These examples are drawn from Christopher B. Mueller and Laird C. Kirkpatrick, Evidence under the Rules 754-55 (2d ed 1993); and James, Hazard, and Leubsdorf, at 348 (cited in note 4).

${ }^{24}$ See, for example, Sharp v Coopers \& Lybrand, 649 F2d 175 (3d Cir 1981).

${ }^{25}$ An interesting example in this regard is the court's ruling in Johnson v Austin, 406 Mich 420, 280 NW2d 9 (Mich 1979), creating a presumption that hit-and-run drivers have behaved negligently in causing the accident. The court's rationale that only a driver who had been negligent (and feared being held liable) would expose himself to a prison term on a hit-andrun charge.

${ }^{26}$ These examples are drawn from James, Hazard, and Leubsdorf, at 349 (cited in note 4). 
accessible to the defendant, rendering his costs lower. Another example is the general rule that the taxpayer bears the burden of proof in income tax deficiency actions brought in the tax court by the Internal Revenue Service. Though the IRS is the plaintiff, the taxpayer is given the burden of proof because he has greater access to evidence concerning his financial affairs. ${ }^{27}$

\section{Prima Facie Cases}

Courts sometimes shift the burden of proof to the defendant on a "prima facie" showing by the plaintiff that $X$ occurred. A well-known instance is found in Title VII antidiscrimination litigation. Suppose the court wants to know whether a group of female employees was discharged for discriminatory reasons. Roughly speaking, if the plaintiffs can show they were treated differently from a group of similarly situated male employees, the defendant must come forward with evidence that the plaintiff was not fired for discriminatory reasons. ${ }^{28}$ In such a setting, $\operatorname{prob}(Y \mid X)$ is relatively high compared to $\operatorname{prob}(Y \mid \sim X)$; in addition, the employer has lower costs of producing evidence on the motive for the discharge.

Similar considerations are at work in the doctrine of "negligence per se," which (in one version) holds that the violator of a safety ordinance is presumed to have acted negligently; once the defendant is shown to have violated the ordinance, he must come forward with evidence he exercised due care. ${ }^{29}$ Here again, $\operatorname{prob}(Y \mid X)$ is relatively high compared to $\operatorname{prob}(Y \mid \sim X$ ), making it sensible to require the defendant to show that $Y$ (violation of the ordinance) was not in fact produced by $X$ (negligence).

\section{Affirmative Defenses}

Courts sometimes shift the burden of proof on a given issue to the defendant by labeling his position on the issue an "affirmative defense." Certain major examples seem consonant with the basic model. For instance, courts typically require the defendant to produce evidence to support his position that the plaintiff assumed the risk in a negligence case; $;^{30}$ one rationale may

${ }^{27}$ See, for example, Portillo v. Commissioner of Internal Revenue, 932 F2d 1128, 1133 (5th Cir 1991).

${ }^{28}$ See, for example, Texas Dept of Community Affairs v Burdine, 450 US 248 (1981).

${ }^{29}$ See, for example, Delfino v Sloan, 20 Cal App 4th 1429, 25 Cal Rptr 2d 265 (1994); Bowen v Baumgardner, 6 Wash App 18, 491 P2d 1301 (Wash App 1971). Another version of the doctrine holds that violation of the statute itself constitutes negligence, rather than just shifting the burden of proof on the question of negligence.

${ }^{30}$ See, for example, William L. Prosser and W. Page Keeton, Prosser and Keeton on the Law of Torts 494 (5th ed 1984). 
be that $\operatorname{prob}(X)$ is very high ( $X=$ victims not assuming risk) since individuals rarely willingly expose themselves to negligently created risks.

Other examples seem explicable by the parties' relative costs. In a tort suit, the defendant generally has the burden of proving his position that he was released from liability by a previous settlement of the dispute. It is presumably far easier for the defendant to prove the fact that a case was settled (by producing a written release) than for the plaintiff to prove it was not. Similar considerations explain why, in a suit to collect payment on a debt, the defendant has the burden of proving he has already paid the debt (it is easy to produce a receipt).

A more interesting example is the issue of contributory negligence in tort suits. The issue arises frequently, yet courts are divided on who should bear the burden on the issue..$^{31}$ Why might this be?

One reason, we conjecture, is that whether (4) is satisfied depends in part on the order in which issues are adjudicated in a case (more precisely, the order in which evidence is presented). Consider two possibilities: in one scenario, the court adjudicates simultaneously the issues of the defendant's care and the plaintiff's care; in the other scenario, it first considers the defendant's care and then (if evidence of defendant negligence is presented) considers the plaintiff's care. In the latter scenario, the court—at the time it adjudicates the issue of the plaintiff's care-has greater reason to believe the plaintiff was careful (see Figure 1). ${ }^{32}$ Thus, when the issues are litigated sequentially, the argument for giving the defendant the burden of proof is stronger.

The division in the courts may reflect disagreement over whether the parties' respective care is generally litigated simultaneously or sequentially. In some instances it makes little sense to examine the issues sequentiallywhen, for example, the same witnesses observed both parties' levels of care, it may be most economical to have them testify on both issues at once. In other instances, the evidentiary materials on each issue may be quite separate, so that it makes most sense to examine the issues sequentially. ${ }^{33}$ The appropriate burden of proof rule (assuming a single rule is to govern both situations $)^{34}$ might then depend on which occurred more frequently. ${ }^{35}$

${ }^{31}$ See, for example, the cases collected in Wigmore, at 479-83 (cited in note 1).

${ }^{32}$ At the beginning of the litigation, the case (for all the court knows) may lie anywhere in the two circles in Figure 1. Once the court knows the defendant has been negligent, it can rule out all nonoverlapping portions of the left-hand circle-meaning it is less probable (than before) that the case in fact lies in the left-hand circle.

${ }^{33}$ For an analysis of related problems, see William M. Landes, Sequential vs. Unitary Trials: An Economic Analysis, 22 J Legal Stud 99 (1993).

${ }^{34}$ Courts could, of course, make the assignment on a case-by-case basis, depending on how the issues would be litigated. As noted above, though, case-by-case determination of the burden of proof has costs of its own.

${ }^{35}$ The orthodox rule in the nineteenth century was to put the burden on the plaintiff; the modern trend is increasingly to put the burden on the defendant. See, for example, Harper, 


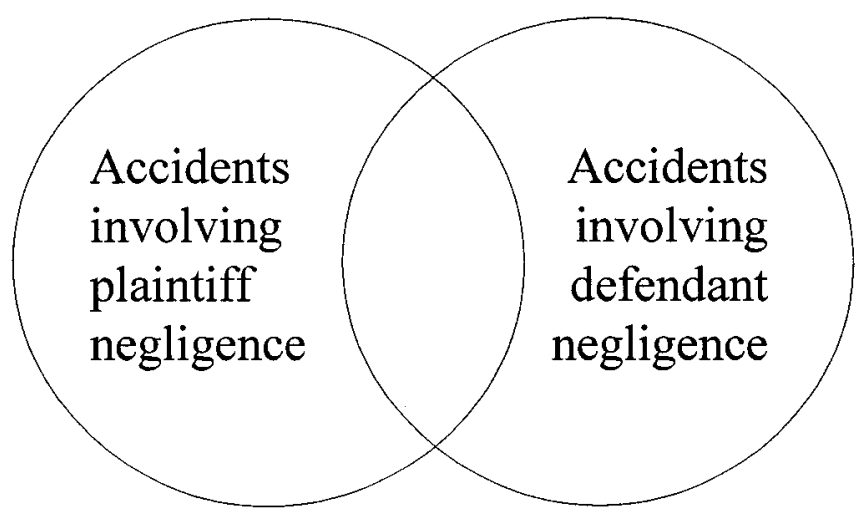

FIGURE 1.-Distribution of negligence cases. Once it is established that the case falls in one circle, the likelihood that it is in the other circle drops.

\section{Concluding Remark: The Choice Between Adversarial AND INQUISITORIAL SYSTEMS}

We have tried to show how, properly employed, the burden of proof assignment may minimize the expected costs of resolving a lawsuit. In our analysis, we have assumed that the court operates within the confines of the adversary system, meaning that it relies on the parties to gather and present evidence. Our analysis also gives some insight on the advantages of an adversary system in comparison to an inquisitorial system, in which the court (or an agency with adjudicative responsibilities) must gather the relevant evidence itself.

Let us suppose that expression (4) holds, so that giving the burden of proof to the plaintiff is preferable to giving it to the defendant on the question whether $X$ occurred in a given case. Assume now that the court can choose between either (i) conducting its own investigation of the matter by gathering evidence on $X$ 's occurrence, or (ii) giving the plaintiff the burden of proof. The latter alternative generates lower litigation costs if the following holds:

James, and Gray, at 347-51 (cited in note 18). Perhaps one explanation is that, in contemporary accident cases, the defendant's conduct is frequently separate (in temporal and spatial terms) from the plaintiff's, so that the evidence on each is also separate. Consider, for example, a product liability case, in which manufacture and use of a product are quite distinct events; evidence about one does not say much about the other. (Other explanations for the modern trend of course include the unpopularity of denying compensation to victims of negligent defendants simply because they themselves have acted negligently - a sentiment reflected, for example, in the widespread adoption of comparative negligence rules.) 


\begin{tabular}{|ll|}
\hline $\begin{array}{l}\text { probability } \\
\text { that } X \\
\text { occurred }\end{array}$ & $\begin{array}{l}\text { plaintiff's costs } \\
\text { of showing } X \\
\text { occurred }\end{array}$
\end{tabular}$<$\begin{tabular}{l}
$\begin{array}{l}\text { court's costs of gathering } \\
\text { evidence of whether } X \\
\text { occurred }\end{array}$ \\
\hline
\end{tabular}

The difference in the two boxes arises because we have assumed that the plaintiff, but not the court, knows what the evidence contains. As a result, if the plaintiff is given the burden of proof, evidence is presented only if (the evidence shows that) $X$ occurred; in contrast, if the court takes the task on itself, it gathers evidence whether or not $X$ occurred.

Expression (5) suggests that the adversary system is likely to produce lower litigation costs unless the court's costs of gathering evidence are considerably lower than the plaintiff's costs of doing so. ${ }^{36}$ (This might be the case if the court has superior access to the evidence, or if the contentiousness of litigation in an adversary system has the effect of generating high costs for the party with the burden of proof. ${ }^{37}$ An interesting question is whether (5) explains patterns actually encountered in practice. We leave this issue for future research.

\section{APPENDIX}

\section{The Burden of Proof and Primary Behavior}

Here we develop the claim advanced in Section IVB3 of the text. Define the following notation:

$k=$ cost of taking care;

$p_{\mathrm{H}}=$ probability of accident if the defendant takes care;

$p_{\mathrm{L}}=$ probability of accident if the defendant does not take care;

$j=$ plaintiff's losses from an accident;

$c=$ a party's cost of presenting evidence (assumed the same for each party).

${ }^{36}$ Shavell's study of appeals makes a similar point about court review of lower court decisions. Rather than automatically reviewing all judgments, it is preferable for the appellate court to force disappointed litigants to come forward (at some cost to themselves) when an error has occurred. In this fashion, the court (assuming its objective is to correct errors) avoids wasting error resources by reviewing decisions that are correct. See Shavell, cited at note 14.

${ }^{37}$ Points commonly raised against the adversarial system are that (1) it invites foot dragging and abusive tactics by the adversaries, and (2) it encourages the manipulation or misleading use of evidence. See, for example, John H. Langbein, The German Advantage in Civil Procedure, 52 U Chi L Rev 823 (1985). Both of these features might have the effect of raising the costs of the party with the burden of proof. (Suppose, for example, that the other party attempts to cloud the litigation with the introduction of unreliable evidence, which the party with the burden of proof must expend effort to refute.) 
We assume that taking care is efficient, meaning

$$
k<\left(p_{\mathrm{L}}-p_{\mathrm{H}}\right) j \text {, }
$$

and also that

$$
c<j \text {. }
$$

Suppose the plaintiff has the burden of proof. Then she will present evidence if injured by the defendant's negligent conduct. The defendant's cost of acting negligently is thus $p_{\mathrm{L}} j$. The defendant, accordingly, will take care if

$$
k<p_{\mathrm{L}} j
$$

which is true anytime (A1) holds.

Suppose, instead, that the defendant has the burden of proof. If he is negligent, he will be held liable in the event of injury; if he is careful, he will not be held liable (though he may bear the costs of proving he was not negligent). He will act carefully if

$$
k+p_{\mathrm{H}} c<p_{\mathrm{L}} j
$$

it is easily verified that this too holds anytime (A1) and (A2) both hold. 
